\title{
Unpublished Mamluk Blazons and Mottos on Glazed Pottery at the Royal Ontario Museum, Toronto, Canada
}

\author{
Moain Sadeq*
}

\section{Introduction}

The Mamluk Sultanate of Egypt lasted from the overthrow of the Ayyubids until the Ottoman conquest of Egypt in 1517. The sultanate's ruling caste was composed of Mamluks, Arabised soldiers of predominantly Kipchak Turk and Circassian slave origin. Though it declined towards the end of its existence, at its height the sultanate represented the zenith of Egyptian and Levantine political, economic, and cultural glory in the Islamic era. Its quasi multicultural character is thus also of relevance when considering the renewal of contemporary Islamic culture and civilisation.

In 1909 and 1988, the Royal Ontario Museum (ROM), Toronto, Canada, acquired an assemblage of 124 fragments of glazed pottery vessels dated to the Mamluk period (1250-1517) in Egypt and Syria. According to the museum records, the objects originated from Cairo, the capital of the Mamluk empire. All objects are wheelmade (i.e. thrown) and for service purposes such as bowls, chalices, cups and plates produced of the Nile clay (earthenware) of Fustat (Old Cairo) and having under-glaze slip painting. The collection has never been studied or displayed and the author has studied them within the framework of his affiliation with the Royal Ontario Museum.

This communication is focusing on sultans' and emirs' blazons and mottos decorating some objects of the unpublished ROM collection and examining them as a line evidence for dating in their historic, art historic and hierarchal contexts.

\section{Blazons of Mamluk Sultans}

The ongoing study of the Mamluk glazed pottery collection attests objects decorated by pictorial images attributed to Mamluk sultans. One of them shows a panther in the act of walking. It is one of the best known blazons of the Mamluk sultans and attributed to the Sultan Baybars al-Bunduqdārī (r. 1260-1277). Inscriptions and artefacts attributed to him are distinguished, particularly, by two panthers symbolising

* Moain Sadeq is Associate Professor of History and Archaeology in Qatar University's Department of Humanities, Doha, Qatar. He would like to acknowledge the Royal Ontario Museum for having given him the permission to study the glazed Mamluk pottery collection, the kind support of Massey College, Toronto, and John Fraser for the generous support of the Aurea Foundation, and Professor Ursula Franklin for her advice and continued support. He also acknowledges the Fogg Museum at Harvard for having given him the opportunity to study its objects deposited at ROM (figs. 4, 6, 7, and 16). Fig. 1-11; 14-18: Photo credit: (C) Moain Sadeq, Courtesy of the Royal Ontario Museum; fig. 12 and 13: Photo courtesy Moain Sadeq. 
his courage and power, most likely in relation to his challenge of the Mongols and Crusaders. According to the chronicle of Ibn Iyās (d. 1522), Baybars attained the panther $\left(s a b^{c}\right)$ as an emblem representing his equestrian and extreme power. ${ }^{1}$ A single walking panther is depicted on Baybars' coins. ${ }^{2}$

One of the ROM Mamluk objects under study (Fig. 1) depicts two panthers resembling those found flanking Baybars' foundation inscriptions and artefacts in Egypt and Syria.

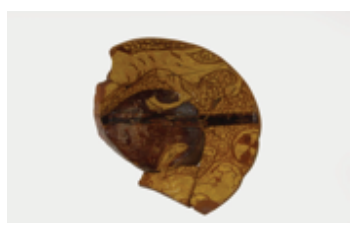

Fig. 1

Mamluk ROM objects show single pictorial images of the eagle, antelope and fish in the central part of the vessel. One of the objects is decorated by the eagle as a personal emblem of the Mamluk sultan Muhammad Ibn Qalā'ūn (r. 1293-1294, 1200-1309, and 1309-1341) depicting it in architecture and material objects made of various materials ${ }^{3}$ as well as on his own coins. ${ }^{4}$ It appears in two varieties - one-headed and the twoheaded - and features both on one or two-fielded shields, and at times even without a shield.

One of the ROM objects displays the antelope, albeit its anatomical proportions are not well drawn. Mayer suggests that mistakes in drawing of pictorial images may be intentionally introduced as a show of humility by artists who might have believed that only Allah can produce perfection. ${ }^{5}$ This suggestion is disputed as many other pictorial images show a high level of correctness in anatomical proportions, for instance as in contemporaneous architecture and artefacts such as the panther of Sultan Baybars and the eagle of Ibn Qalā'ūn.

Although we do not have any data evidencing the antelope as an emblem for Mamluk sultans or emirs, it was always a favourite hunting animal for Muslim rulers since the Umayyad period. It is, for instance, painted in the hunting scenes of the Umayyad palaces, such as in Qusayr ${ }^{\mathrm{C}}$ Amrah in the Jordanian desert. ${ }^{6}$

Another object displays the horse as a single image. The art historian Muștafã suggests the horse as a further emblem for the post-dispatcher, ${ }^{7}$ whose fess in the middle of a three-register emblem is well-known and widely displayed in architecture and material culture (see Fig. 2).

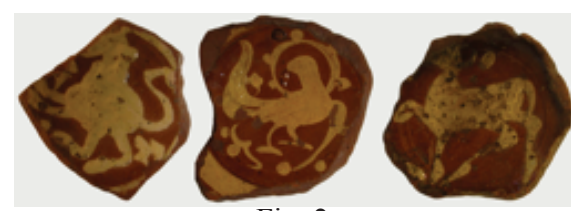

Fig. 2 


\section{Cartouches of Mamluk Sultans}

In addition to theses heraldic pictorial images, the Mamluk sultans also had their own inscribed shields (cartouches) depicted in an oval form in architecture and artefacts. The early shields of this type were simple and started during the early Mamluk period constituting three fields or horizontal stripes, of which the middle one bears the sultan's name. Such shields appear alone or besides emir emblems, as discussed below, on one of the ROM Mamluk objects. Sultan blazons developed during the Late Mamluk (Circassian) Burjī period (1382-1517) constituting three fields documenting the sultan's name and epithets accompanied by blessings as mentioned below.

\section{Blazons of Mamluk Emirs}

The Mamluks developed a heraldic science for emirs as well. Each prominent emir had his own blazon, mostly circular and decorated with the heraldic device reflecting his official post. Each emir depicts his emblem in architecture and on every possible belonging dedicated to him. Although many questions are still open concerning the meaning of some heraldic devices, blazons are considered as one of the first-hand sources for the structure and organisation of the emir class as blazons represent the office held by the emir at the time of his being made emir. The emir changes his heraldic device when changing his office, but there are some emirs whose blazons remained unchanged such as the emir Yūnus al-Nawrūzī and Manjak al-Yūsufĩ. In case the emblems were chosen or granted by the sultan, the emirs retained them for the whole of their lives. They could be adopted by another emir at their deaths. Sanjar al-Ghawlī, the governor of Gaza, for instance, claimed/adopted the blazon of his friend Sālār after his death (it was piebald, ablaq, according to al-Maqrīzī). ${ }^{8}$

\section{Emir Blazons among ROM Objects}

Emblems of emirs depict the following heraldic devices: five objects display the cup as a heraldic device of the cup-bearer $(s \bar{a} q \bar{\imath})$. Generally, in other collections elsewhere in the world, the number of cupbearers is greater than that of any other blazon groups and the cup is the most frequently occurring heraldic device. ${ }^{9}$ This is most likely due to the large number of cupbearers for the various members of the sultan's family and elite. In addition, it is attested that the sons of cupbearers inherited the emblems of their fathers after death even if the sons were not appointed as cupbearers. The cup as a heraldic device appears in various forms and sizes. We see its location in the central register of the blazon or depicted in big size covering the whole blazon space. ${ }^{10}$ We also notice in inscriptions and biographies that there are differences between a cupbearer $(s \bar{a} q \bar{\imath})$ and a taster (jashnigīr). 


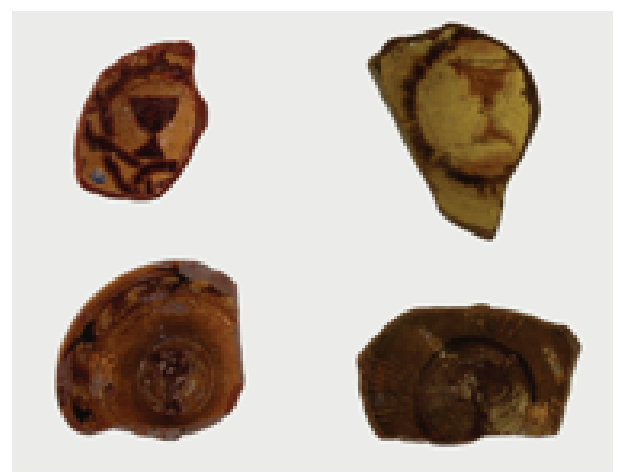

Fig. 3

Blazons of food-tasters (jashngìr) usually consist of large round plates, sometimes with, sometimes without, a support or a stand for the plates $(a t \underline{a} \bar{q} q)$, called in Mamluk literature khanjah. Ibn Batțūțah (d. 1368 or 1369), for instance, says that they (the elites in Cairo) use a copper table called khanjah. It is a small table (or circular stand) used as a stand for a plate called talam. ${ }^{11}$ This is also attested by the Mamluk chronicler al-Maqrīzī (d. 1442 CE). ${ }^{12}$

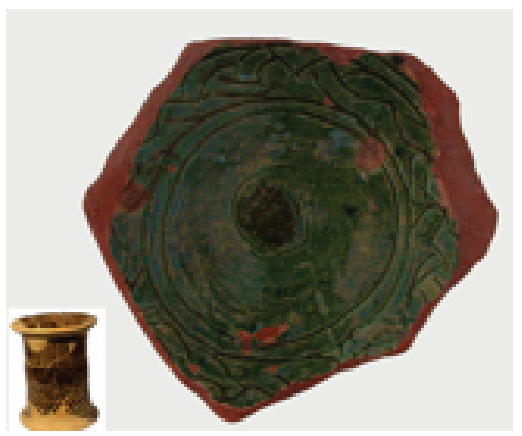

Fig. 4

The sword (with sword notes), or sometimes a pair of swords, or a sword together with a crescent or horseshoe, is the emblem of the armour-bearer (silāhdār ). Besides the sword, the Mamluk blazons of the armour-bearer also display the scimitar, the dagger, and the battle-axe as emblems while the bow is the device of the bowman (bunduqdār), who was of the same rank as the armour-bearer. 


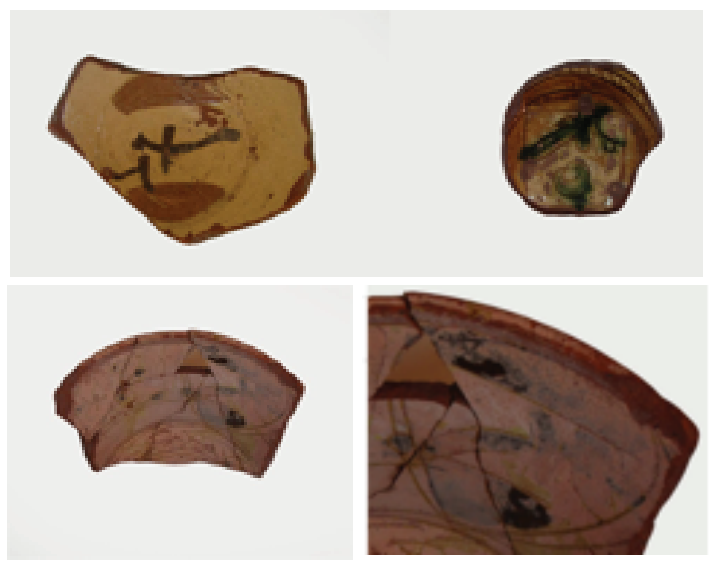

Fig. 5

It is observed in the Mamluk heraldry that the blazon of the dispatch-rider ( $\operatorname{bar} \bar{\imath} d \bar{\imath})$ is divided into three horizontal shields. The middle one has a dark bar which is the fesse or fess (fascia, a horizontal band forming the middle third of a shield), representing a strip of cloth that was customarily wrapped around the arm of the dispatch-rider.

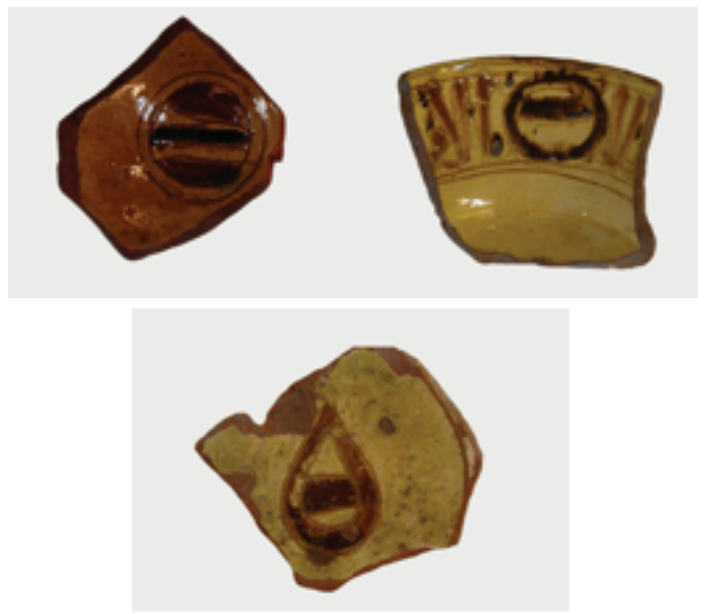

Fig. 6

Two flags on two poles decorate one of the ROM Mamluk objects. A single flag or sometimes two flags on one pole are displayed in Mamluk blazons. This heraldic device represents the official post of the flag master ( ${ }^{c}$ alamdār). ${ }^{13}$ 


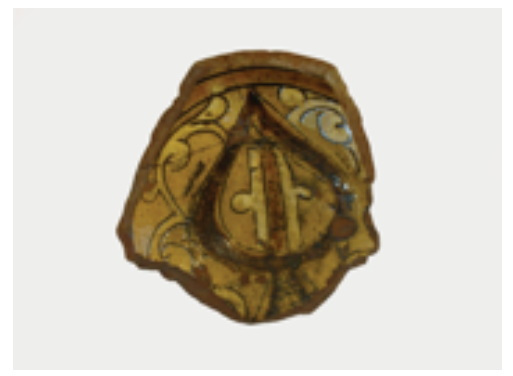

Fig. 7

The blazon of the stable master $(a m \bar{i} r \bar{a} k h \bar{u} r)^{14}$ appears on the ROM Mamluk objects with and without a shield. This blazon shows a device in a horseshoe, reflecting, according to the Damascene historian Abū 'l-Fidā' (d. 1331) the post of the master of the stable amīr $\bar{a} k h \bar{u} r$. This blazon also appears in combination with other charges/ devices such as napkins or is placed alongside or between two identical devices (e.g. with a sword). This blazon (Fig. 8) can also be interpreted as a crescent and in this case might be related to an emir responsible for one of the Mamluk posts, keeping in mind that the crescent (or moon) is an essential element in Islamic religion and culture and also has relevance to agricultural issues. This type of blazon has disappeared entirely with the introduction of the composite blazon on three-fielded shields during the Late Mamluk period.

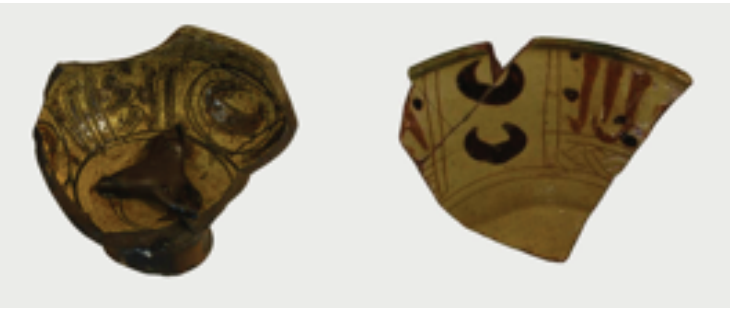

Fig. 8

The six-petalled rosette (Fig. 9) was very popular during the Bahrī Mamluk period (1250-1382) as it was depicted on artefacts and buildings either as a single heraldic device or with other devices as discussed below. ${ }^{15}$ It was used as an emblem by the sultans of the Rasulids in Yemen (r. 1229-1454). ${ }^{16}$ Al-Qalqashandī (d. 1418) states that the rosette is attributed to sultans and emirs of the Qalā'ūn family. 


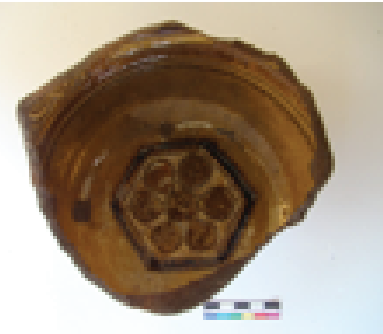

Fig. 9

A tamghah (or tamga) is an abstract seal or device used as emblem of a particular tribe, clan or family. They were common among the Huns and Mongols ${ }^{17}$ and were used as emblems during the late Ayyubid period (r. in Egypt 1171-1250, in parts of Syria until 1341) and are also seen on objects dated to the Mamluk period. It is shown in the bottom of one of the ROM Mamluk objects.

\section{Emir Emblems Depicting Sultan Cartouches}

As discussed above, the display of blazons of sultans appears sometimes side by side with blazons of emirs. This is observed on one of the ROM objects showing the blazon of the food-taster (jashnigitr) together with a cartouche bearing the sultan's name in the middle field. The upper and lower fields are left blank.

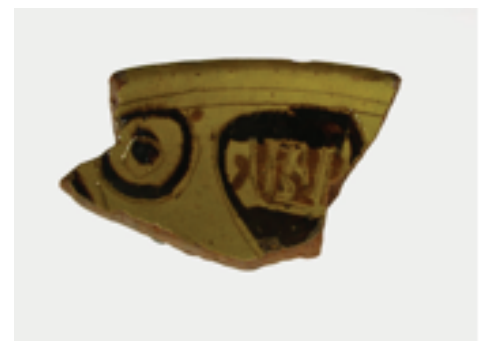

Fig. 10

Another example of an emir emblem combined with a sultan cartouche is observed on one of the ROM objects. The emir heraldic device here is the napkin (buqjah) of the master of the wardrobe (jamdār). A napkin (buqjah) is a piece of cloth in which clothes and chancery deeds were wrapped. It appears in either a square or rhomb form. The sultan cartouche on the object has partially survived and is attributed more likely to a sultan of the Early Mamluk period as it is simple and divided into three fields displaying the sultan's name in the middle. The combination of a sultan 
cartouche with an emir blazon on one object or in architecture is most likely a sign of loyalty to the sultan.

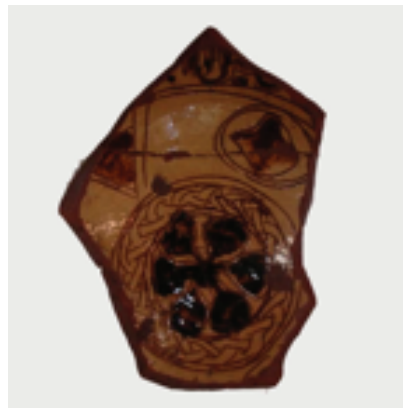

Fig. 11

The combination continued until the Late Mamluk period, but both of them (the sultan cartouche and the emir blazon) are developed, meaning that the sultan inscription, as discussed above, covers the three fields or stripes of the cartouche and a number of heraldic devices cover the three fields of the emir composite blazon. One example (see Fig. 12 and 13), albeit in architecture, depicted on the façade of the caravanserai of the emir Yūnus al-Nawrūzī in the city of Khān Yūnus, $23 \mathrm{~km}$ south of Gaza, depicts on both sides of the gate opening two identical blazons of the emir Yunus flanking the cartouche of Sultan Barqūq (r. 1382-1389 and 1390-1399). ${ }^{18}$

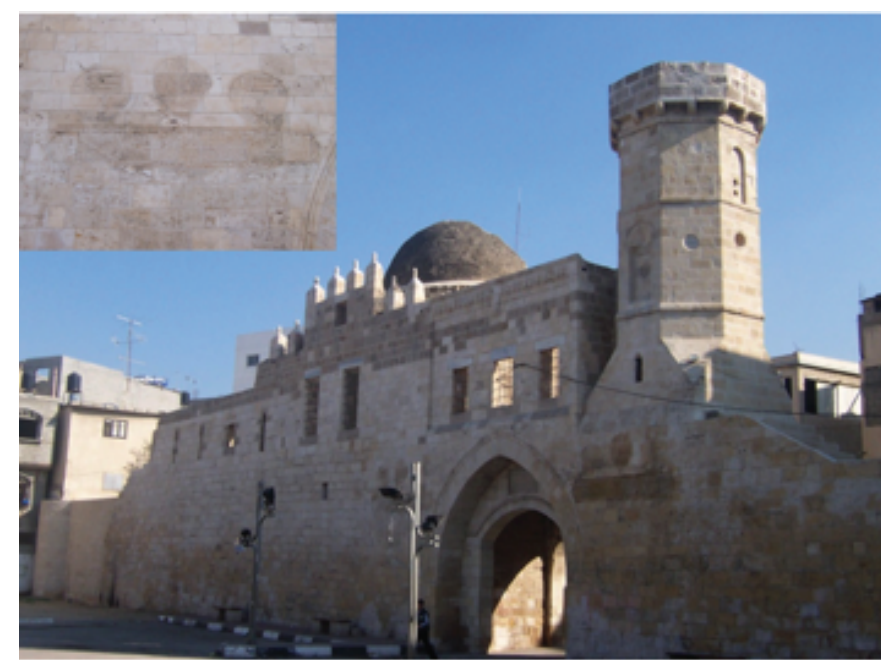



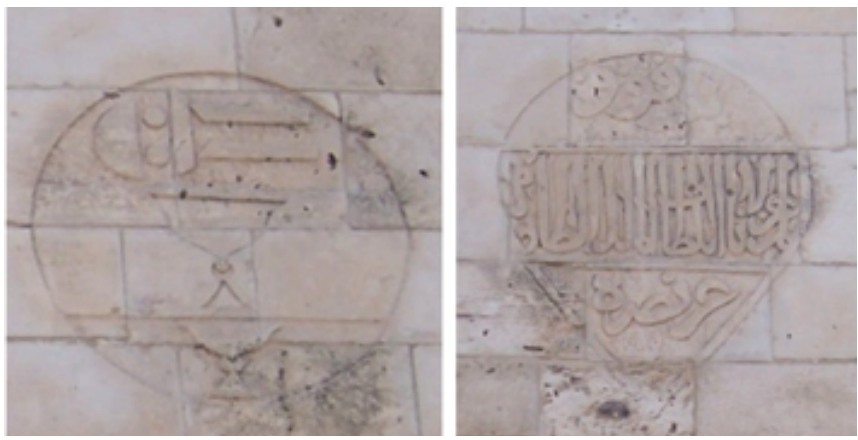

Fig. 12 and 13 (photo courtesy Moain Sadeq)

\section{Pictorial Images of Possible Emblems}

Two of the ROM objects display fishes in the central location of the vessels. The fish is one of the decorative elements repeatedly produced on Byzantine (Christian) mosaic pavements of churches and monasteries excavated by the author in Gaza. In Christianity, fish, among other food items, is mentioned in connection with some of the miracles of Jesus Christ (such as reported in Luke 5:1-11 or in John 21-1-14). Fish are also depicted on the famous Byzantine mosaic map of Madaba (Jordan), particularly with reference to the river Jordan. On our objects (see Fig. 14), fish imagery is most likely meant to be an emblem designated for high-ranking official posts or as merely decorative elements produced for the Christian community for whom (as well as for the Jews) the Mamluks appointed their own religious judges.

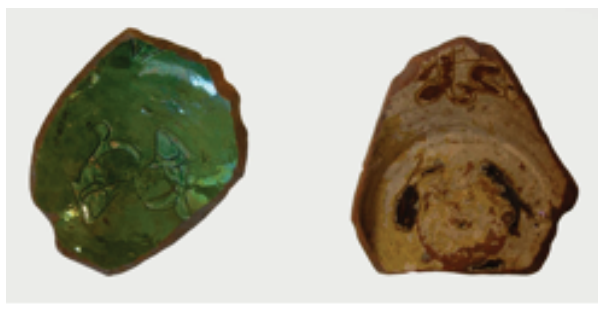

Fig. 14

The hexagon is a geometric decorative element that is often seen engraved in Islamic architecture and displayed on artefacts. It is also a major element decorating one of the ROM objects. The hexagon is one of the known decorative elements seen on stone, wood, and artefacts as well as on Ayyubid coins. It can be interpreted here as a merely Islamic geometric decoration and might also have had some designation to Jewish judges serving under the Mamluks or to a high-ranking Jewish community member. 


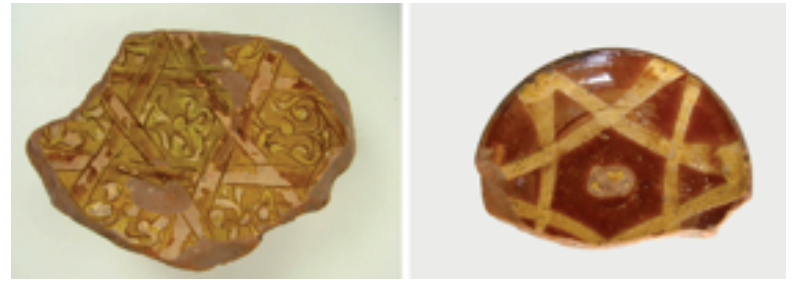

Fig. 15

\section{Emirs' Mottos and Epithets on ROM Objects}

Two large chalice fragments in the ROM collection are decorated with naskhi calligraphy containing epithets attributed to Mamluk emirs evidencing the attribution of the emirs' high rank at the Mamluk court. One of them is a chalice fragment with partially surviving inscriptions stating the following:

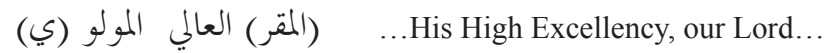

(المقر الأشرف) العالي المولو (ي) ...His most Noble and High Excellency, our Lord...

Two other inscriptions on chalice fragments say:

The most magnificent emir.

The well served, the most magnificent.

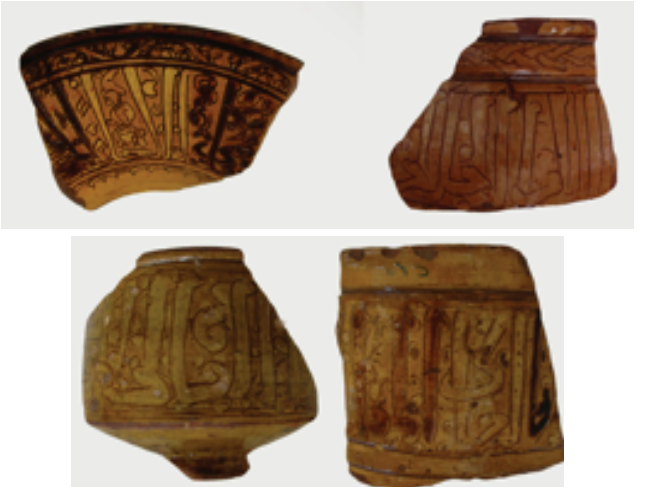

Fig. 16 
In Islamic art mottos and epithets are also to be found on other materials such as metal and stone. The following text decorates a Mamluk copper basin in the Museum of Islamic Art in Cairo (No. 7852). ${ }^{19}$ It says:

$$
\text { تما عمل بمل برسم المقر الأشرف العالي المولوي المالكي العالمي العادلي السيفي }
$$

This is one of the objects made for His Most Noble and High Excellency, our Lord, the royal, the learned, the just, Sayf al-Dīn Tankiz, Viceroy of the noble provinces of Syria, the protected.

In architecture we see such epithets and mottos engraved on a window lintel of the mausoleum of the emir Baybars al-Jāliq al-Ṣāliḥ̂i in Jerusalem. The text says:

$$
\begin{aligned}
& \text { بسم الله ... هذه تربة الأمير الأجل الكبير الغازي المحاهد المرابط في سبيل }
\end{aligned}
$$

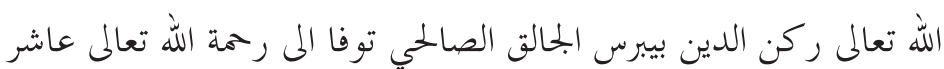

$$
\begin{aligned}
& \text { جمادى الأول سنة سبع وسبعمائة غفر الله له ولمن دعا له بالرحمة. }
\end{aligned}
$$

In the Name of Allah [...]. This is the mausoleum of the most magnificent and Great Emir, the Vanquisher, the Defender of the Faith, the Warrior at the Frontiers in the path of Allah the Exalted, Rukn al-Dīn Baybars al-Jāliq al-Ṣalihịī. Passed into the mercy of God the Exalted on 10 Jumada I of the year 707 [7 November 1307], may Allah forgive him and whosever asks (Allah's) mercy for him.

Other epithets attributed to emirs on ROM three objects such as المخدومي (the wellserved) and المترمي المخدومي (the honoured, the served) are mentioned frequently in Mamluk architecture and arts (see Fig. 17).

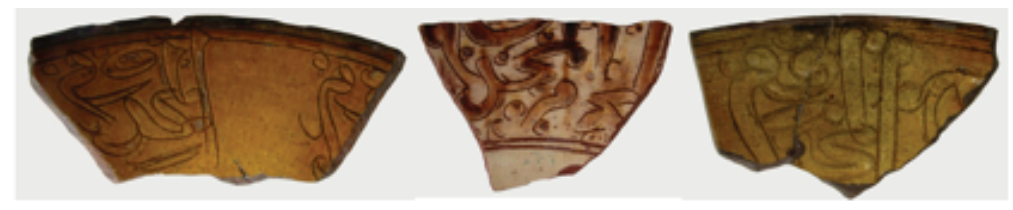

Fig. 17

The following is a complete Mamluk inscription including these epithets:

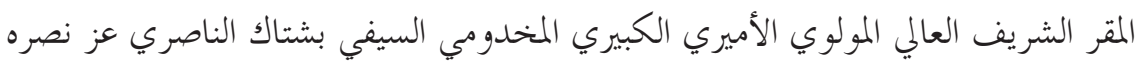

His Noble and High Excellency, our Lord, the Great Amir, the Well-served, Sayf al-Dīn Bashtāk al-Nāṣirī, May his victory be glorious. 
In addition to the epithets attributed to the emirs, the ROM Mamluk ceramic collection includes an object (see Fig. 18) decorated with a calligraphy dedicated to a judge. The inscription says:

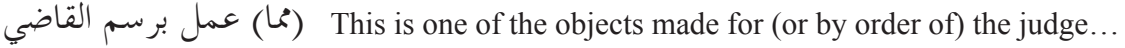

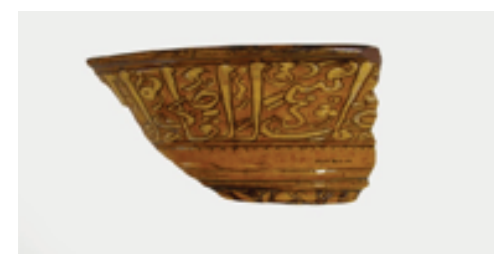

Fig. 18

\section{Conclusion}

The first hand data of the author's ongoing study of the glazed pottery at the ROM of a wide range of objects sheds light on unpublished Mamluk cartouches and emir blazons in their historic, art historic, and hierarchal contexts. As discussed in this communication, the collection provides the scholarly community with additional examples of pictorial blazons attributed to Early Mamluk sultans such as Baybars and Ibn Qalā'ūn.

- The ongoing study also sheds light on early inscribed cartouches of the Mamluk sultans representing the first developmental phase of the cartouche genre during the Early Mamluk period. The cartouche is a three-fielded shield bearing the sultan's name in the middle field while the other two fields are left blank. They appear on objects either alone or together with the emir blazon. In the latter case the vessel is designated to the emir while the depiction of the sultan's name is merely a sign of the emir's loyalty to his master.

- The emir blazons of the ROM objects are circular and simple characterising the Muslim heraldry of the Early Mamluk period. They depict solely the heraldic device in a circular shield symbolising the official post of the emir. Some pictorial and geometric decoration such as fish and hexagons still require further study in order to determine safely whether they are emblems of specific high-ranking officials or merely decorative elements. 
- None of the emir blazons in the collection represents the advanced phase of Muslim heraldry in which one blazon may depict/represent more than seven heraldic devices serving as 'a curriculum vitae' for the present and previous posts of an explicit emir. Such composite blazons are characteristic for the Late Mamluk period (referred to also to as the 'Circassian' or 'Burjī' period) and hence offer strong evidence for dating the objects to the Early (Bahrī) Mamluk period.

- The calligraphy of the objects is an important primary source for mottos and epithets of the Mamluk emirs at that time. They are also evidence for the vessel dating as this communication has worked to match the mottos and epithets decorating the objects with other complete and well-dated inscriptions in architecture and material culture.

- This communication attests that the selected objects are service vessels of high quality. Their blazons, decorations, mottos, epithets, and nashkī script do attest their attribution to the Mamluk elite, and particularly to sultans and high-ranking emirs on service.

- Finally, the blazons and calligraphy are solid dating evidence for the objects' technology and typology and hence provide important well-dated primary data for further studies in Mamluk history, art history, Mamluk organisational behaviour - and ultimately the history of Islamic civilisation in general.

\section{Notes}

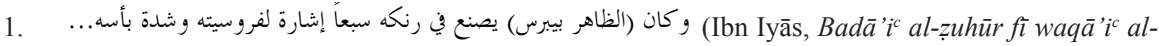
duhūr, ed. Muḥammad Mușṭafā (Cairo: al-Hay’ah al-Mișriyyah al-'Āmmah li '1-Kitāb, 1982, $2^{\text {nd }}$ ed.), vol. 1, pt. 1, p. 341.

2. P. Balog, "The Coinage of the Mamluk Sultans of Egypt and Syria," Numismatic Studies 12 (1964), 163 (No. 206).

3. A. 'Abd al-Rāziq, "Aḍ̂ā̄' jadīdah [...]," paper submitted at the Hittin Forum, organised by the Egyptian Society for Historical Studies, Cairo, 1988, p. 3.

4. Balog, "The Coinage," 163 (No. 206).

5. L. Mayer, Saracenic Heraldry (Oxford: Oxford University Press, 1933).

6. K. A. C. Creswell and James W. Allan, A Short Account of Early Muslim Architecture revised and supplemented by J. W. Allan (Aldershot, United Kingdom: Scholar Press, 1989), 105-126.

7. Muḥammad Mușțafā, Al-wiḥdah fì 'l-fann al-islāmī (Cairo: Maṭbū̄āt al-Jumhūriyyah al-'Arabiyyah al-Muttahidah, 1958).

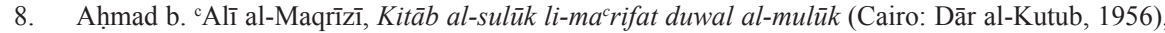
2:74; L. Mayer, "Le blason de l'Amir Salar," Journal of the Palestine Oriental Society 5 (1925), 27-33.

9. Mayer, Saracenic Heraldry, 29.

10. A. 'Abd al-Rāziq, "Aḍ̂ā' jad̄̄dah," 82.

11. مائدة من النحاس يسموفا خوبجة ويجعل عليها طبق نحاس يسمونه الطال 
gharā'ib al-amșār wa cajā’ib al-asfār, ed. Karam al-Bustānī (Beirut: Dār al-Șādir, 1964), 4:69.

12. al-Maqrīzī, Kitāb al-sulūk, 1:444.

13. Ibid., 5:463; Mayer, Saracenic Heraldry, 5.

14. This office was of particular importance in the Turkic-Persianate world; on its significance in Safavid Persia, see Christoph Marcinkowski, Mirza Rafi'a's Dastur al-Muluk: A Manual of Later Safavid Administration. Annotated English Translation, Comments on the Offices and Services, and Facsimile of the Unique Persian Manuscript (Kuala Lumpur: ISTAC, 2002), 124-126 and 319-320.

15. Mayer, Saracenic Heraldry, 6.

16. A. 'Abd al-Rāziq, "Aḍ̂ā̄' jadīdah,” 82.

17. A Mongolian term; see also Marcinkowski, Mirza Rafi'a's Dastur al-Muluk, 113 n. 297, 263-264 n. 133 , and 602 .

18. M. Abu Khalaf, "Khan Yunus and the Khans of Palestine," Levant 15 (1983), 178-186.

19. Mayer, Saracenic Heraldry, 222. 